\title{
sciendo
}

Research Article

(C) 2019 Kornchanok Boonthon and Thanin Ratanaolarn. This is an open access article licensed under the Creative Commons Attribution-NonCommercial-NoDerivs License (http://creativecommons.org/licenses/by-nc-nd/3.0/).

\section{Designer Competency of the Fashion Design Undergraduate Students in Thailand: A Need Assessment Perspective}

\author{
Kornchanok Boonthon \\ Ph.D., Candidate in Industrial Education, \\ Faculty of Industrial Education and Technology, \\ King Mongkut's Institute of Technology Ladkrabang (KMITL), Thailand \\ Thanin Ratanaolarn \\ Ph.D., Assistant. Prof., \\ Faculty of Industrial Education and Technology, \\ King Mongkut's Institute of Technology Ladkrabang (KMITL), Thailand
}

Doi: 10.2478/mjss-2019-0060

\begin{abstract}
This study used a mixed approach research design. The objectives were to study employers' and college instructors' needs regarding the designer competencies of undergraduate fashion-design students in Thailand, and to propose a guideline for the development of designer competencies of undergraduate fashion-design students in Thailand. For the quantitative approach, the research samples included 250 business owners/designers and 163 college instructors from fashion design faculties in Thai universities. A questionnaire was used as the research instrument. Data were collected by email. A "need-assessment analysis" technique was implemented in the data analysis. Regarding the qualitative approach, 15 key informants were interviewed via the interview script. A "content analysis" technique was used to analyse the qualitative data in this research. The results revealed that the employers' need for improved components of knowledge competencies was consistent with the need of college instructors: both placed a priority on the development of language knowledge, followed by productmanagement knowledge, innovative knowledge and design knowledge. The employers' need for improved components of skill competencies was consistent with the need of college instructors: both placed a priority on the development of language skills, followed by product-management skills, innovative and technology skills, and design skills. The employers' need for improvement of qualification competencies was consistent with the need of college instructors: both placed a priority on the social role, followed by inner drive and self-conceptualisation, respectively. However, the findings indicated a difference between their needs: employers found that none of the qualification competencies needed rapid development, whereas college instructors indicated that one component needed rapid improvement - the social role.
\end{abstract}

Keywords: Designer, designer competency, students' competency, fashion design, fashion-design students

\section{Introduction}

The fashion industry is a huge market, with a global value of US\$1.3 trillion per year. The retail of fashion clothing alone, not including footwear or jewellery, is just a little bigger than the Russian economy, or almost equivalent to the gross domestic product (GDP) of the world's 126 poorest countries put together (CODA, 2019). The fashion industry not only generates income for countries, but also provides a large number of jobs. For instance, an estimated 1.8 million people are 
employed in the fashion industry in the USA (World Bank JEC Democratic, Bureau of Labor). Average annual wages in the fashion industry range from US $\$ 26,440$ to US $\$ 84,600$ for marketing and sales managers. Moreover, there are around 18,000 designers, whose average annual wage is US\$73,690, meaning that they receive over US\$30 per hour (Brunton \& Jeffrey, 2010).

The clothing market in Thailand is worth 3,186 million baht, and the market value for fashion clothing exports had reached US\$7,459.81 million in 2014 (Best Living Taste Magazine, 2019). Moreover, the Government Savings Bank has forecasted that the clothing market would continue to grow with the growth of e-commerce (Government Savings Bank, 2019). Although there are no official statistics about the number of people employed in the fashion industry, it was estimated that around a million jobs are provided by the fashion business (Ministry of Labour and Welfare, 2015). From this background, we can see that human resources are crucial in driving the success of the industry. Businesses with highly competent employees have a higher competitive advantage than those with poorly competent employees.

"Competency" refers to a mixture of skills, knowledge, attributes and behaviours that allow an individual to perform a task or an activity successfully within a given job (Leach, 2008). Therefore, employees with high competency have a tendency to work more effectively and, consequently, are desired by employers (Cardy \& Selvarajan, 2006).

Universities are educational institutes whose mission is to generate highly competent human resources in accordance with the need of the labour market (David \& Motala, 2017). In order to generate competent undergraduate fashion-design students for the fashion industry, the competency of designers, in response to employers' demands, should be determined. This can be used as a guideline for universities to improve and develop students' competencies to meet with employers' needs.

Due to the significance of designer competencies in the fashion-clothing industry, the researcher wanted to conduct a study on "Designer Competencies of Undergraduate FashionDesign Students in Thailand: A Need-Assessment Perspective". The results can be used as a guideline for developing the competencies of undergraduate fashion-design students to meet with the requirements of employers in the fashion industry, and will consequently enhance the competitive advantage of the Thai clothing industry in the future.

\section{Research Objectives}

1. To study employers' needs regarding designer competencies of undergraduate fashiondesign students in Thailand.

2. To study instructors' needs regarding designer competencies of undergraduate fashiondesign students in Thailand.

3. To propose a guideline to develop the designer competencies of undergraduate fashiondesign students in Thailand.

\section{Literature Review}

This research was conducted based on the following literature.

\subsection{The Concept of Competency}

A competency is typically defined as a combination of skill, knowledge, attribute and behaviours that enables an individual to perform a task or an activity successfully within a given job (Leach, 2008). Competencies are observable behaviours that can be measured and evaluated and, therefore, are essential in terms of defining job requirements and recruiting, retaining and developing staff (Lichtveld et al., 2008).

Competencies enable the staff of an organisation to have a clear understanding of the behaviours to be exhibited and the levels of performance expected in order to achieve organisational results. Competency (Neiworth et al., 2014) provides the individual with an indication of the behaviours and actions that will be valued, recognised and rewarded. Using a competency 
framework enables an organisation to successfully align its staff's skills, capabilities and knowledge with organisational priorities, resulting in business improvement and efficiencies (Englander et al., 2013).

Competencies are widely used across an organisation and are embedded in all human resource management functions, such as planning, recruitment, performance management and staff development. They are determined by occupational roles and responsibilities, and the complexity of duties outlined in job descriptions (Ruiz, 2012).

- For planning, competencies are applied in job design, which involves the determination of the job content, the requirements to carry out the job and the relationships between the job holder and other staff. In this context, competencies ensure that the attributes, skills and behaviours necessary to achieve the highest performance standards for a given job are specified.

- For recruitment, competencies form an integral part of the selection process, facilitating the assessment of candidates to determine their suitability for a given job.

- For performance management and staff development, competencies facilitate the establishment of performance standards against which staff will be assessed, and the identification of individual and organisation-wide staff-development priorities.

Competencies can be classified into the following six types (Devkar \& Kalidindi, 2013; Durand, 2000; Liang, Howard \& Leggat, 2017):

1. Individual competency: this type refers to a person's own knowledge, skills, and attitudes (behaviour) that contribute to effectiveness in performance, as well as in dealings with other people.

2. Business competency: this refers to the knowledge and skills required in a particular business or industry.

3. Management competency: this refers to a set of competencies that are applicable only to supervisory and managerial positions or roles, which are more commonly task-oriented.

4. Leadership competency: this refers to the required competencies for leadership roles such as that of a team leader. These competencies make an individual effective in their position as leader of a group.

5. Functional competency: this type of competency is specific to a certain job. For example, a computer programmer must be knowledgeable and skilled when it comes to various programming languages such as Java, Python, and $\mathrm{C}++$.

6. Core competency: this refers to general competencies specific to an organisation; it is the way the organisation and its members work.

In this study, the researcher focused on studying the "functional competency" of designers in the fashion-design business.

\subsection{Professional Qualification and Functional Competency}

In order to develop the quality of Thai human resources to international standards, the Thai Professional Qualification Institute (TPQI) was set up as the main agency responsible for developing a system of professional qualifications, which is an important mechanism to improve the progress and productivity rate of manpower in Thailand (TPQI, 2019). This institute has joined with industry groups and those involved in identifying the competencies that an industry needs in order to create "occupational standards", which means determining the level of competency of the person in the profession and also certifying skills and expertise by creating standards for performance measurement in order to certify "professional qualifications". These professional qualifications will directly benefit the majority of people who do not have a high level of education but have experience and expertise in the profession. The TPQI has provided professional qualifications to a wide range of occupations, such as management, aviation, finance, education, food and beverage production, and fashion designers, etc. (Vicheanpant, 2009).

According to the TPQI, the competencies of fashion designers include being able to (TPQI, 
2019):

- Communicate and analyse consumer needs, fashion, and dress styles.

- Plan team meetings, fashion, and dress styles to present the design strategy within the organisation.

- Plan fashion-design strategies and dress styles.

- Define the concept of fashion design and commercial dress style to match the organisation's policy.

- Present ideas for use in fashion design and dress styles for those involved.

- Study and analyse strategies and the distribution of commercial products with the design of dress patterns.

- Analyse and create information into systems for use in the development of fashion design, dress styles, etc.

The competencies were integrated in developing a competency framework which comprised three components, as presented in figure 1.

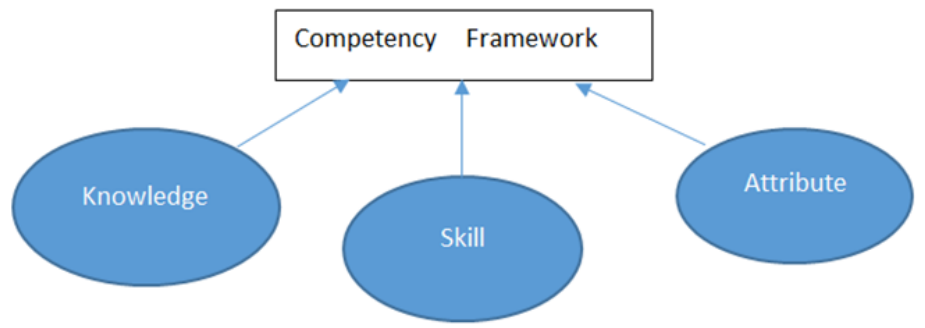

Figure 1: Adapted from TPQI’s Competency Framework (TPQI, 2019)

In this study, the competency framework and fashion design professional competencies were adapted to the research framework and the development of the research instruments (see figure 2).

\subsection{Research Framework}

\begin{tabular}{|c|c|c|c|c|}
\hline \multicolumn{2}{|c|}{ Input } & \multicolumn{2}{|c|}{ Process } & Output \\
\hline \multicolumn{2}{|c|}{ Initial Designer Competencies } & \multicolumn{2}{|c|}{ Need Assessment Analysis } & \\
\hline $\begin{array}{l}\text { Concept and } \\
\text { Theory } \\
\text { obtained } \\
\text { from } \\
\text { literatuxe } \\
\text { review }\end{array}$ & $\begin{array}{l}\text { Fashion } \\
\text { Designer } \\
\text { Qualificati } \\
\text { on } \\
\text { (TPQI) }\end{array}$ & $\begin{array}{l}\text { Employers } \\
\text { / } \\
\text { Designers } \\
\text { needs }\end{array}$ & $\begin{array}{l}\text { Faculty } \\
\text { need }\end{array}$ & $\begin{array}{l}\text { Designer } \\
\text { Competencies of } \\
\text { undergraduate } \\
\text { students in Thailand. }\end{array}$ \\
\hline
\end{tabular}

Figure 2: The Research Framework

\section{Research Procedure}

This study used a mixed method research design whereby the qualitative and quantitative research approaches were integrated. The details of the research procedure are as follows. 


\subsection{The Quantitative Research Approach}

\subsubsection{Research population and samples}

\subsubsection{Research population}

The research population included two groups, which were:

1. Business owners/designers of leading fashion clothing businesses in Thailand.

2. College instructors from fashion design faculties in Thai universities.

\subsubsection{Sample size}

The research samples included 250 business owners/designers and 163 college instructors.

\subsubsection{Sampling technique}

Purposive sampling was implemented to select business owners/designers of leading fashiondesign businesses whose companies offered training programmes to undergraduate fashion-design students. It was also used to select college instructors from fashion design faculties from every university in Thailand.

\subsubsection{Research instrument}

A questionnaire was used as the research instrument in this study. It was developed based upon the concepts and theories concerning competency and designer qualifications, as designated by the Thai Professional Qualification Institute (TPQI, 2009).

\subsubsection{Structure of the questionnaire}

The questionnaire comprised two parts:

- Part I: the respondents' personal information. This part contained seven closed-ended multiple choice questions concerning gender, age, education, work experience, occupation, type of workplace, and name of company.

- Part II: the respondents' needs regarding designer competencies of undergraduate students in Thailand. This part was divided into three components:

1. Knowledge competency, containing 14 rating-scale questions.

2. Skill competency, containing 33 rating-scale questions.

3. Attribute competency, containing 29 rating-scale questions.

\subsubsection{Testing for validity and reliability}

The questionnaire was tested for its validity and reliability before being used for the data-collection process.

\subsection{Content validity}

The questionnaire was sent to three experts in the fashion-design field. They were asked to rate their opinions about the consistency of each question and the objectives of the research. The Index of Congruency (IOC) was used to judge the validity of each question. Questions with an IOC value lower than .05 would be eliminated. However, no question in the questionnaire received an IOC value of less than 0.5 ; therefore, all questions were retained. 


\subsection{Reliability}

A pilot test was executed with 30 designers who were not included in the research samples. Cronbach's alpha coefficient was used to determine the reliability of the questionnaire. The result yielded the value of Cronbach's alpha coefficient for each part as follows:

1. Knowledge competency: 8.89 .

2. Skills competency: 9.25 .

3. Attributes competency: 8.75 .

The outcome indicated that this questionnaire had high reliability and could be used for data collection.

\subsubsection{Data collection and analysis}

The URL of the questionnaire was embedded on Google Forms and was sent to the sample via 500 emails. However, only 413 questionnaires were completed

Data analysis was done through a "need-assessment analysis" technique. The statistics used in this process were:

1. Frequency and percentage were used to describe respondents' personal information.

2. Mean value was used to indicate the respondents' level of need.

3. Modified Priority Needs Index ( $\mathrm{PNI}_{\text {modified }}$ ) was used to indicate the respondents' priority of needs.

\subsection{The Qualitative Research Approach}

\subsubsection{Key informants}

Key informants included five designers, five fashion-clothing business owners and five college instructors in the fashion-design field.

\subsubsection{Research instrument}

The interview script was developed based upon the concepts and theories concerning competencies and designer qualifications, as designated by the Thai Professional Qualification Institute (TPQI, 2009).

\subsubsection{Structure of the script}

The semi-structural interview script comprised three parts, as detailed:

1. Part I asked about the interviewees' requirements regarding a designer's knowledge competencies.

2. Part II asked about the interviewees' requirements regarding a designer's skill competencies.

3. Part III asked about the interviewees' requirements regarding a designer's attribute competencies.

\subsubsection{Test of content validity}

The interview script was submitted to the experts to examine the correctness and the congruence between the questions and the objectives of the study. 


\subsubsection{Data collection and analysis}

Data collection was administered according to the following processes:

1. The researcher made an interview appointment with the interviewee via telephone.

2. The researcher went to interview the interviewee at the date and time of the appointment and used a voice recorder to record the interview.

3. The researcher transcribed the voice record file in order to be ready for data analysis in the next step.

A "content analysis" technique was used to analyse the qualitative data in this research.

\section{Research Findings}

In this section, the outcomes of the analysis results are summarised in tables 1-6.

Table 1: Employers' priority need index ( $\mathrm{PNI}_{\text {modified }}$ ) in respect of knowledge competency

\begin{tabular}{|l|c|c|c|c|}
\hline Components & $\overline{\mathbf{x}}_{\text {real }}$ & $\overline{\mathbf{x}}_{\text {expect }}$ & PNI $_{\text {modified }}$ & Order \\
\hline 1. Design knowledge & 3.32 & 4.45 & 0.339 & 4 \\
\hline 2. Product-management knowledge & 2.82 & 3.93 & 0.394 & 2 \\
\hline 3. Innovation and technology knowledge & 2.97 & 4.11 & 0.385 & 3 \\
\hline 4. Language knowledge & 2.80 & 4.11 & 0.470 & 1 \\
\hline
\end{tabular}

The findings from table 1 reveal that the $\mathrm{PNI}_{\text {modified }}$ values are between 0.339 and 0.470 . Of the four components, three rapidly need to be developed: (1) language knowledge ( $\mathrm{PNI}$ modified $=0.470)$; (2) product-management knowledge $\left(\mathrm{PNI}_{\text {modified }}=0.394\right)$; and (3) innovation and technology knowledge $\left(\mathrm{PNI}_{\text {modified }}=0.385\right)$.

Table 2: Instructors' priority need index ( $\left.\mathrm{PNI}_{\text {modified }}\right)$ in respect of knowledge competency

\begin{tabular}{|l|c|c|c|c|}
\hline Components & $\overline{\mathbf{x}}_{\text {real }}$ & $\overline{\mathbf{x}}_{\text {expect }}$ & PNI $_{\text {modified }}$ & Order \\
\hline 1. Design knowledge & 3.34 & 4.52 & 0.354 & 4 \\
\hline 2. Product-management knowledge & 2.83 & 4.06 & 0.436 & 2 \\
\hline 3. Innovation and technology knowledge & 3.00 & 4.27 & 0.422 & 3 \\
\hline 4. Language knowledge & 2.84 & 4.28 & 0.507 & 1 \\
\hline
\end{tabular}

The findings from table 2 reveal that the PNI modified values are between 0.354 and 0.507 . Of the four components, three rapidly need to be developed: (1) language knowledge $\left(\mathrm{PNI}_{\text {modified }}=0.507\right)$; (2) product-management knowledge $\left(\mathrm{PNI}_{\text {modified }}=0.436\right)$; and (3) innovation and technology knowledge $\left(\mathrm{PNI}_{\text {modified }}=0.422\right)$.

As observed from tables 1 and 2, the employers' need for improved components of knowledge competencies was consistent with the college instructors: both placed priority on the development of language knowledge, followed by product-management knowledge, innovative knowledge, and design knowledge, respectively.

Table 3: Employers' priority need index ( $\mathrm{PNI} \mathrm{modified}_{\text {) }}$ in respect of skills competency

\begin{tabular}{|l|c|c|c|c|}
\hline Components & $\overline{\mathbf{x}}_{\text {real }}$ & $\overline{\mathbf{x}}_{\text {expect }}$ & $\mathbf{P N I}_{\text {modified }}$ & Order \\
\hline 1. Designing skills & 3.31 & 4.31 & 0.303 & 4 \\
\hline 2. Product-management skills & 2.85 & 4.06 & 0.424 & 2 \\
\hline 3. Innovation and technology skills & 2.89 & 4.09 & 0.417 & 3 \\
\hline 4. Language skills & 2.55 & 4.10 & 0.608 & 1 \\
\hline
\end{tabular}

The findings from table 3 reveal that the $\mathrm{PNI}_{\text {modified }}$ values are between 0.303 and 0.608 . Of the four 
components, three rapidly need to be developed: (1) language skills ( $\left.P N I_{\text {modified }}=0.608\right)$; (2) product-management skills $\left(\mathrm{PNI}_{\text {modified }}=0.424\right)$; and $(3)$ innovation and technology skills $\left(\mathrm{PNI}_{\text {modified }}\right.$ $=0.417)$.

Table 4: Instructors' priority need index ( $\left.\mathrm{PNI}_{\text {modified }}\right)$ in respect of skills competency

\begin{tabular}{|l|c|c|c|c|}
\hline Components & $\overline{\mathbf{x}}_{\text {real }}$ & $\overline{\mathbf{x}}_{\text {expect }}$ & PNI $_{\text {modified }}$ & Order \\
\hline 1. Designing skills & 3.36 & 4.44 & 0.324 & 4 \\
\hline 2. Product-management skills & 2.84 & 4.14 & 0.458 & 2 \\
\hline 3. Innovation and technology skills & 2.91 & 4.19 & 0.440 & 3 \\
\hline 4. Language skills & 2.52 & 4.20 & 0.670 & 1 \\
\hline
\end{tabular}

The findings from table 4 reveal that the $\mathrm{PNI}_{\text {modified }}$ values are between 0.324 and 0.670 . Of the four components, three rapidly need to be developed: (1) language skills ( $P N I_{\text {modified }}=0.670$ ); (2) product-management skills $\left(\mathrm{PNI}_{\text {modified }}=0.458\right)$; and $(3)$ innovation and technology skills $\left(\mathrm{PNI}_{\text {modified }}\right.$ $=0.440)$.

As observed from tables 3 and 4, the employers' need for improved components of skills competencies was consistent with the college instructors: both placed a priority on the development of language skills, followed by product-management skills, innovative and technology skills, and design skills, respectively.

Table 5: Employers' priority need index ( $\mathrm{PNI}$ modified $)$ in respect of attribute competency

\begin{tabular}{|c|c|c|c|c|}
\hline Components & $\overline{\mathbf{x}}_{\text {real }}$ & $\overline{\mathbf{x}}_{\text {expected }}$ & $\mathbf{P N I} I_{\text {modified }}$ & Order \\
\hline 1. Social roles & 3.38 & 4.31 & 0.277 & 1 \\
\hline 2. Self-concept & 3.62 & 4.43 & 0.222 & 3 \\
\hline 3. Inner drive & 3.53 & 4.51 & 0.275 & 2 \\
\hline
\end{tabular}

The findings from table 5 reveal that the $\mathrm{PNI}_{\text {modified }}$ values are between 0.222 and 0.277 which is lower than 0.3. Therefore, none of these components has a rapid need for development.

Table 6: Instructors' priority need index (PNImodified) in respect of attribute competency

\begin{tabular}{|l|c|c|c|c|}
\hline Components & $\overline{\mathbf{x}}_{\text {real }}$ & $\overline{\mathbf{x}}_{\text {expected }}$ & $\mathbf{P N I}_{\text {modified }}$ & Order \\
\hline 1. Social roles & 3.36 & 4.41 & 0.313 & 1 \\
\hline 2. Self-concept & 3.66 & 4.56 & 0.246 & 3 \\
\hline 3. Inner drive & 3.61 & 4.66 & 0.292 & 2 \\
\hline
\end{tabular}

The findings from table 6 reveal that the $\mathrm{PNI}_{\text {modified }}$ values are between 0.246 and 0.313 . Of the three components, one aspect rapidly needs to be developed: the social role $\left(\mathrm{PNI}_{\text {modified }}=0.313\right)$.

As observed from tables 5 and 6, the employers' need for improved attribute competencies was consistent with the college instructors: both placed a priority on the social role, followed by inner drive, and self-conceptualisation, respectively. However, the findings indicated a difference between their needs. Employers found that none of the attribute competencies needed rapid development, whereas college instructors indicated that one component (the social role) needed rapid improvement.

\section{Discussion and Recommendations}

In order to explain and extend the knowledge from this study, in the following section the research findings are discussed in accordance with the research objectives. 


\subsection{To Study Employers' Needs Regarding Design Competency of Undergraduate Fashion- Design Students in Thailand}

From the research findings, employers indicated the rapid need to improve three components of knowledge competencies: (1) language knowledge; (2) product-management knowledge; and (3) innovation and technology knowledge, respectively. This result reflects that, nowadays, advances in technology, communication and transportation have facilitated cross-country global trade among businesses. To be able to do business with foreigners, language knowledge is essential. However, the employers found that the undergraduate fashion-design students had much lower language knowledge than they would expect; therefore, they indicated that students' language knowledge competencies should be rapidly developed. Moreover, students' product-management knowledge was also lower than what the employers would expect it to be; this might due to the college curriculum, which may not be responding to the requirements of fashion design employers.

Additionally, in this digital era, technology has changed rapidly. Designers' innovation and technology knowledge is important as it allows them to benefit from and take advantage of using technology. Therefore, from the employers' perspective, students' innovation and technology knowledge needs to be improved.

Regarding the skills competency, the employers indicated the rapid need to improve three components of skills competencies: (1) language skills; (2) product-management skills; and (3) innovation and technology skills, respectively. This result reflects that, currently, advances in technology, communication and transportation have facilitated cross-country global trade among businesses. To be able to do business with foreigners, language skills are essential. However, the employers found that the undergraduate fashion-design students had much lower language skills than they would expect; therefore, they stated the rapid need to improve students' language skill competencies. Moreover, students' product-management skills were also lower than employers would expect; this might be due to the college curriculum, which might not be responding to fashion design employers' requirements.

As for the attribute competency, employers did not find that any component of the qualification competency needed rapid development. This result implies that, even though the real qualification competency of the students was lower than employers expected, the distance between their real competency and employers' expectations was not so much that employers felt it needed rapid improvement.

\subsection{To Study Instructors' Needs Regarding Design Competency of Undergraduate Fashion- Design Students in Thailand}

From analysis of the results, the instructors stated their need to rapidly improve three components of knowledge competencies: (1) language knowledge; (2) product-management knowledge; and (3) innovation and technology knowledge, respectively. The result symbolised that, currently, communication with foreigners has become more important in doing business globally. Therefore, language knowledge is essential. However, the instructors found that the undergraduate fashiondesign students had much lower language knowledge than they would expect; therefore, they indicated that the students' language knowledge competencies should be rapidly developed. Moreover, students' product-management knowledge was also lower than what the instructors expected; this might be due to the college curriculum, which is not keeping pace with the current business situation.

Furthermore, in this digital era, technology has changed rapidly. A designer's innovation and technology knowledge is important as it allows designers to benefit from and take advantage of using technology. Therefore, from the instructors' perspective, the innovation and technology knowledge of the students needed to be improved.

In respect of the skills competency, the instructors indicated the rapid need to improve three components of skills competencies: (1) language skills; (2) product-management skills; and (3) innovation and technology skills, respectively. As mentioned, technology today allows businesses to 
expand to an international level. When doing business with foreigners, language skills are essential. However, the instructors found that the undergraduate fashion-design students had much lower language skills than they should have. Therefore, the instructors stated their rapid need to improve students' language-skill competency.

Besides this, the students' product-management skills were also lower than what they were expected to be. This might due to the college curriculum, which did not respond to the requirements of fashion-design employers.

As for the attribution competency, the instructors found one component that needed rapid development - the social role. This may be because the social role has not been included in the design curriculum. Therefore, it is up to the instructors to consider whether they want to cultivate students' social-role consciousness.

In comparison, the employers' need for improved components of knowledge competency was consistent with the need of college instructors: both placed a priority on the development of language knowledge, followed by product-management knowledge, innovative knowledge, and design knowledge, respectively. This agreement between employers and instructors confirmed that students' language knowledge, product-management knowledge, and technology and innovative knowledge need rapid development.

Moreover, the employers' need for rapid improvement of components of skills competencies was consistent with the need of college instructors: both placed a priority on the development of language skills, followed by product-management skills, and innovative and technology skills, respectively. This result also assured that students' language skills, product-management skills, and innovative and technology skills were in need of rapid improvement.

Additionally, the employers' need for improved attribute competencies was consistent with the need of college instructors: both placed a priority on the social role, followed by inner drive and selfconceptualisation, respectively. However, the findings indicated a difference between their needs. Employers found that none of the attribute competencies needed rapid development, while college instructors indicated that one component, the social role, needed rapid improvement. This result reflects that the qualification of the students regarding social roles, inner drive and self-actualisation are not crucial from the point of view of employers and instructors.

\subsection{To Propose a Guideline for the Development of Design Competencies of Undergraduate Fashion-Design Students in Thailand}

The research findings indicate the need to develop designer competencies for undergraduate fashion-design students in Thailand, in order to be consistent with employers' requirements. Moreover, developing the fashion design competency of undergraduate students will help Thai universities to generate higher-qualified students for the labour market. In order to improve the designer competency of undergraduate students, the following recommendations should be implemented:

1. Universities should recognise the importance of foreign languages and should add foreign language courses to the curriculum, whether optional or mandatory, in order to enhance the designer competency of the students regarding language knowledge and language skills.

2. Universities should review and develop the product-management curriculum to enhance the designer competency regarding product-management knowledge and skills, so that students can work successfully in the fashion-design business.

3. Universities should consecutively introduce new technology to the classroom so that students learn to use the new technology in their studies and their profession.

4. Universities should review and develop the design curriculum to enhance the designer competency regarding product-management knowledge and skills so that students can work successfully in the fashion-design business.

5. Universities should organise activities to enhance the attributes of the undergraduate students, such as inner-drive, self-conceptualisation and social roles. 


\section{References}

Best Living Taste Magazine (2019). "Fashion door to move forward in the global economic arena" [Online] Available: http://www.bltbangkok.com/CoverStory/. (November 12, 2018)

Brunton, M., \& Jeffrey, L. (2010). Using the critical incident technique for triangulation and elaboration of communication management competencies. Journal of Vocational Education \& Training, 62(3), 239-255.

Cardy, R. L., \& Selvarajan, T. (2006). Competencies: Alternative frameworks for competitive advantage. Business Horizons, 49, 235-245.

CODA (2019). Size of the global fashion retail market: [Online] Available: https://www.commonobjective.co/article/the-size-of-the-global-fashion-retail-marketThe Size of the Global Fashion Retail Market. (Junuary 15, 2019)

David, S.A. \& Motala, S. (2017). Can BRICS Build Ivory Towers of Excellence? Giving New Meaning to the World Class Universities. Research in Comparative and International Education, 12(4), 512-528.

Devkar, G. A. \& Kalidindi, S. N. (2013), "Modeling and Assessment of Competencies in Urban Local Bodies for Implementing Projects", Built Environment Project and Asset Management, 3(1): 42-57.

Durand, T. (2000). "The Alchemy of Competence",French Review of Management,127(1): 84 - 102.

Englander, R. Cameron, T. Ballard, AJ. Dodge, J. Bull, J.\& Aschenbrener, CA. (2013). Toward a common taxonomy of competency domains for the health professions and competencies for physicians. Acad Med. 2013;88(8):1088-1094.

Government saving bank, (2019). Industrial trend and Clothes (2018-2019) [Online] Available: https://www.gsb.or.th/getattachment/2a4c817b-139b-4365-87af-18ab459bdd84/textile_61_62.aspx (January 12, 2019)

Leach, D.C. (2008). Competencies: from deconstruction to reconstruction and back again, lessons learned. Am J Public Health. 98(9), 1562-1564.

Liang, Z., Howard, P. F. \& Leggat, S. G. (2017). " $360^{\circ}$ Management Competency Assessment: Is Our Understanding Adequate?" Asia Pacific Journal of Human Resources, 55(2), 213-33.

Lichtveld, M. Boulton, M. Lemmings, J. \&Gale J. (2008). From competencies to capacity: assessing the national epidemiology workforce. Public Health Rep.123(1),128-135.

Neiworth, L. Allan, S. D Ambrosio, L. Coplen- Abrahamson, M. (2014). Charting a course to competency: An approach to mapping public health core competencies to existing trainings. Health Promot Pract. 15(1), 33S-38S.

Ruiz, Y. Matos, S. Kapadia, S. Islan, N., Cusack, A., Kwong, S., \&Trinh-Shevrin, C. (2012).

Lessons learned from a community-academic initiative: the development of a core competency-based training for community-academic initiative community health workers. Journal of Public Health. 102(12), 23722379.

Thai Professional Qualification Institution (TPQI), (2009). Professional standards.[Online] Available: http://www.tpqi.go.th/standard.php. (October 12, 2018)

Vicheanpant, T. Survey of the Requirement Competency of Digital Media Designer. Sriprathum Academic Journal Chonburi. 26-30. 